especially when, at the beginning, these are struggling to cooperate with each other.

Research and development may also suffer under the new arrangements. Who, for example, will ensure that the new authorities will not needlessly duplicate each other's work? Will there be a rash of schemes for ground water development when carefully selected pilot studies would be better? Will there be ten pilot desalination plants when a smaller number would be sufficient? And who, under the new arrangements, will plan and execute the long-term schemes which may easily be larger in scale than the vision of the regional authorities, however large, can encompass? Much, of course, will depend on the balance of power between the regional authorities and the new Water Council, which may yet have more bite than at present appears likely. But the danger is that if the government does not get the balance right, there will be a return to the position before the Water Resources Act of 1963, and the balkanization of British water resources.

\section{Time for Change in Spain}

Ever since the Second World War, Spain has been conspicuous among the nations of Western Europe for its backwardness in scientific research and development. The OECD has now published the thirteenth of its Reviews of National Science Policy, Spain (£0.85), which is for one thing a more explicit criticism of the machinery used by a member government for regulating domestic science policy than the OECD has ventured so far and also, by all accounts, something of a landmark in Spanish affairs.

The diagnosis which the OECD's review team has presented goes a long way to explain why Spain has for a long time been too remotely connected with the rest of the scientific community. For one thing, the amounts of money spent on research and development are too small, whatever yardstick is used for measurement. In 1967, the government and industry between them appear to have spent 3,837 million pesetas ( $£ 22.7$ million) on research and development of all kinds. This amounts to 0.27 per cent of the GNP of Spain in 1967, a somewhat flattering statistic when it is remembered that the per capita GNP was roughly a third of that of Belgium, for example. Throughout the 1960s, industry and the government in Spain seem to have been contributing almost equally to the total cost of research and development, but almost all of what the government spent was channelled through its own research centres, with the result that only three per cent of all intramural expenditure was in university research. How, it will be asked, can a modern state expect to run a university system with just over $£ 600,000$ for research? In the circumstances, it is clearly something of a miracle that Spanish universities have been able to win a high reputation for themselves.

The OECD review has also drawn attention to serious anomalies in the way in which the government's own expenditure has been channelled through the government research institutes. In spite of the importance of agriculture in Spain, expenditure on agricultural research in 1967 amounted to only 375 million pesetas, 17.4 per cent of all government expenditure on research and development. Moreover, between 1967 and 1969, the budget of the Alonso de Herrera Foundation, which supports the work of several important agricultural research centres, declined by almost a fifth. On the face of things, it seems as if the Ministry of Agriculture had had early wind of the Rothschild proposals, for direct expenditure by the ministry was increasing. Of the small sums available for research and development, 23 per cent were devoted in 1967 to nuclear energy, and although the OECD review says that this may be entirely proper if indeed Spain is to generate a great deal of its electricity from nuclear power stations later in this decade and in the 1980s, this allocation of priorities must seem to outsiders to be misplaced.

The OECD review committee has several suggestions for reform, many of which were by all accounts discussed at a confrontation with Spanish officials in Madrid in the summer of 1970. Briefly, it urges that the government of Spain must choose between "the pattern of the past" and radical departures from it. It argues that research and development will make valuable contributions to the balance of payments, both in agriculture and in industry - the Ebro research centre has done well in agriculture, but elsewhere progress has been disappointing. The report is tart in its strictures on the government's neglect of university research, and pleads for the involvement of the universities in long-term planning-it could with advantage have said more about the need to improve the status of university research and to increase its scale. What would this cost? In round numbers, the OECD asked for a doubling of government expenditure on research and development as a first step. Luckily, there is now at least a chance that some part of this message will be heeded.

\section{Years Ago}

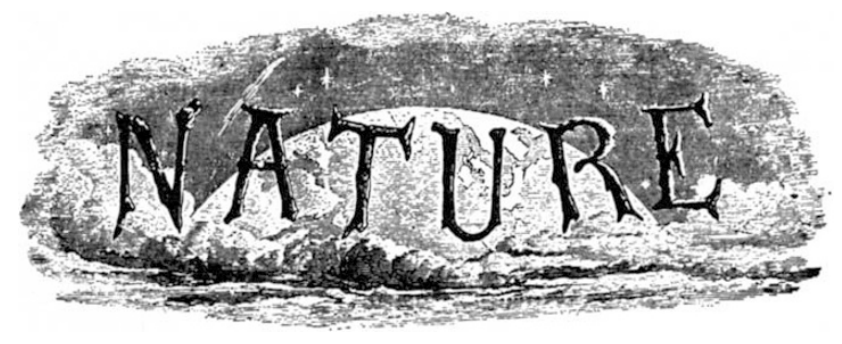

The Rigidity of the Earth

Although, as he truly says, Sir W. Thomson's arguments for the rigidity of the earth have never been astacked, yet they have undoubtedly been too long ignored; and it is gratifying to see them asseited by their authur in NATURE. Allow me, however, to remark on one sentence near the end of his quotation frum the "Natural Pn losopny," where Mr. Hupkins's observation is given, that the distr thution of fluid matter withen the earth is " piobably quive local." Unless I am mistaken, Mr. Hopkins's opinion was, that its d stribui in is, as one might say, fortuitous. But, as I have elsewhere olseived, the trains of volcanoes which accomprany many of the great lines of elevation for enormous distances re der the motion of such local distri «tion of fluid matter highly improbuble, unless it be admitted that its presence is due to mountain elevations as a cause. I have suggested that this fluidity may arise from a dimini-heit pressure beneath mountain ratuses, owng to their mass being partly sup. ported by the lateral thrust which has upraised them-a supposition which Mr. Scrope had already appliel to account for an incr asted fluidity in the heared rock underlying a volcanic vent, whe! from any cause the pres ure became les.

If any of your correspondents can propose another explanation of this remarkable coincidence comparible with the supposition of a rigid globe, it would be interesting to know it.

Iarltun, Cambridge

O. FISHER 